\title{
II-1antagonist Treatment in Recurrent Aseptic Meningitis Related to Familial Mediterranean Fever
}

\author{
Ruth Livny \\ Rambam Health Care Campus https://orcid.org/0000-0002-9598-3059 \\ Yuval Bitterman \\ Rambam Health Care Campus \\ Riva Brik \\ Rambam Health Care Campus \\ Yonatan Butbul Aviel ( $\sim$ yonatanbutbul@gmail.com ) \\ Rambam Health Care Campus
}

\section{Case Report}

Keywords: FMF, recurrent aseptic meningitis, colchicine resistance

Posted Date: September 8th, 2020

DOl: https://doi.org/10.21203/rs.3.rs-71444/v1

License: (-) (i) This work is licensed under a Creative Commons Attribution 4.0 International License. Read Full License 


\section{Abstract}

\section{Background}

Familial Mediterranean fever (FMF) is an autosomal recessive, auto-inflammatory disease, presenting with recurrent bouts of fever and polyserositis. FMF has been associated with central nervous system (CNS) manifestations such as Headache and Myalgia. The occurrence of other forms of nervous system involvement is rare, including seizures, sinus vein thrombosis, pseudotumor cerebri and more. There are only few case reports of aseptic meningitis due to FMF.

\section{Case presentation}

We present the case of a 14 year-old girl diagnosed with FMF, who experienced recurrent episodes of severe headache and aseptic meningitis while on maximal dose of colchicine therapy. She had a dramatic response to anakinra with symptoms resolving completely within a few days without recurrence. Subsequently, we identified seven cases in the literature describing recurrent aseptic meningitis in patients with underlying FMF; all showed response to colchicine treatment, without treatment failure.

\section{Conclusion}

Our case suggests a role for Interleukin 1 (IL-1) antagonists for cases of CNS involvement secondary to FMF in patients who fail to respond to colchicine, and might imply that anakinra could be effective in other auto-inflammatory diseases with CNS involvement.

\section{Background}

Familial Mediterranean fever (FMF) is the most common monogenic, auto-inflammatory disease, mostly found in Sephardic Jews, Armenians, Turks, and Arabs. FMF manifests as recurrent self-limiting attacks of fever and serositis, such as peritonitis, pleuritis, pericarditis, and arthritis ${ }^{1}$. The estimated number of patients globally exceeds 100,000 , with 10,000 in Israel alone. The MEFV gene encodes for an inflammation regulatory protein termed Pyrin, which seems to comprise part of an inflammasome NLRP3 that regulates the level of IL-1b (interlukin 1-b), and thereby the degree of inflammation ${ }^{2}$. Neurological manifestations include headache accompanying FMF febrile attacks, and different types of muscle pain. Other nervous system manifestations are rare, and their relationship to FMF uncertain. These manifestations include seizures, sinus vein thrombosis, pseudotumor cerebri, optic neuritis, polyarteritis nodosa, multiple sclerosis, ischemic stroke and recurrent aseptic meningitis (RAM) ${ }^{3,4}$.

Colchicine has been shown to be effective in controlling inflammation in the majority of FMF patients, however, colchicine resistance is well described in the literature ${ }^{4}$. For these patients, a therapeutic alternative for colchicine is needed. Based on the role of pyrin in the regulation of interleukin (IL)-1 $\beta$ activation, the efficacy of IL-1 inhibitors has been assessed in few case series ${ }^{56}$. The three commercially available anti IL-1 drugs today are anakinra, rilonacept and canakinumab. In most patients, anakinra (recombinant non-glycosylated homolog of the human IL-1 receptor antagonist (rhlL-1Ra)) significantly improved abdominal pain and fever, and decreased FMF attacks. The relief of symptoms was evident within a very short period of time, accompanied by a rapid decline of inflammatory parameters such as Serum Amyloid A (SAA) and C-reactive protein. ${ }^{7}$

In literature, few reports about the safety and tolerability of anakinra therapy in patients with FMF or rheumatoid arthritis have been published. One of the most commonly observed has been pain at site injections as well as local cutaneous reactions. Uncommonly, Patients with previous pneumonia or other risk factors for lung infections may have an increased risk to develop infectious complications of the respiratory system. Cytopenia as its potential side effect is generally mild. ${ }^{25}$

In this case-based review, we present a pediatric patient with FMF, who suffered from acute chronic headaches and presented with three proven episodes of RAM while on colchicine and response dramatically to treatment with anakinra. We compare this patient to previously described patients with FMF who contracted aseptic meningitis.

\section{Case Presentation}

A 14 year old, Sephardic Jewish girl was diagnosed with FMF at 7 years of age, based upon typical clinical attacks of abdominal pain accompanied by fever and recurrent erysipelas-like reaction. She has several family members with FMF, and genetic studies showed homozygosity to M694V mutation. After treatment with $2 \mathrm{mg} /$ day of colchicine, she was doing fairly well with occasional abdominal pain attacks.

For the past two years, she suffered recurrent episodes of acute headaches (for several weeks, resolved spontaneously) and was hospitalized on several occasions. Her headaches were described as occipital, awakening from sleep, and were accompanied by fever, nausea and photophobia. During these attacks no meningeal signs or neurological deficits were found on physical examination, and funduscopic examination was normal on several occasions. Between acute episodes she had chronic headaches of lesser severity. She underwent a thorough work up including MRI, MRA, and spinal taps on three occasions. All spinal taps specimens showed pleocytosis with 55-200 cells/ml, with lymphocytic predominance and normal to mild increase in protein levels (40-75 mg/ml). Opening pressures and Glucose levels were normal; bacterial cultures and serology tests for $\mathrm{Q}$ fever and toxoplasma were negative. PCR examinations in search of different viral pathogens, including HSV-2, were negative. CSF cytology was normal. Blood CRP levels were elevated $(13-103 \mathrm{mg} / \mathrm{L})$ during the attacks, and then returned to normal $(0-5 \mathrm{mg} / \mathrm{L})$. Neurological consult described the complaints pattern as acute on chronic headaches due to atypical migraine, with pleocytosis. 
After a presumptive diagnosis with RAM due to FMF, 100 mg/day of anakinra, an II-1 interleukin 1 (IL1) receptor antagonist drug was added to colchicine treatment and all headaches resolved completely within a few days. Currently she has been treated with anakinra for $>36$ months, with resolution of both headache and FMF attacks.

Subsequently, a systematic search of the literature was performed retrieving English-language original case reports, case series, case-based reviews, and review articles on aseptic meningitis in FMF patients, up to January 2020. Pubmed/MEDLINE was queried for "familial Mediterranean fever" and "aseptic meningitis". Articles involving patients with FMF suffering from aspetic meningitis, recurrent or single episode - were included ${ }^{8,9,10,11,12}$.

Publications not detailing treatment modalities were excluded. Information obtained in a systematic fashion included demographics, FMF diagnostic criteria, treatment and outcomes.

In addition to our case, as of January 2020, we identified seven articles with seven cases describing aseptic meningitis in patients with underlying FMF; 6 of 7 cases were described in the adult population, with patient age ranging from 32 to 64 years of age, two (including our case) were in the pediatric population (13 and 14 years old). All cases in the literature responded well to colchicine treatment and aseptic meningitis episodes were diminished.

\section{Discussion And Conclusions}

We describe a case of RAM caused by FMF according to current diagnostic standards ${ }^{13}$. Acute headache attacks coincided with exacerbation of her FMF in most attacks and were accompanied by high inflammatory markers and laboratory characteristics of aseptic meningitis, with chronic headaches between episodes. The events continued despite colchicine treatment, and resolved after adding anti IL-1 receptor treatment.

Central nervous system (CNS) manifestations of FMF are rare and under debate. Neurologic involvement associated with FMF shows a wide spectrum,

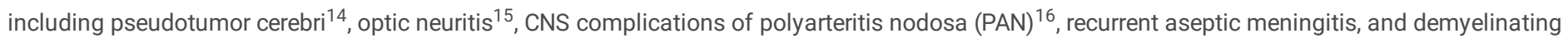
lesions ${ }^{17}$.

Primary headaches are common among FMF patients, although believed to be unrelated to the immunologic illness itself ${ }^{18}$. Nonetheless, there are several reports of headaches due to recurrent episodes of RAM presumed to be related to FMF, mainly in adults (Table 1). In most cases, events subsided or resolved following colchicine treatment, however, reports are scarce and vary significantly in criteria for FMF diagnosis (with or without genetic proof). This makes it difficult to determine whether the headaches resulted from aseptic meningitis. Furthermore, not all reports addressed response to treatment. 
Table 1

Previous Cases of Recurrent Meningitis Associated with Familial Mediterranean Fever (FMF

\begin{tabular}{|c|c|c|c|c|c|c|c|c|c|c|}
\hline Reference & $\begin{array}{l}\text { Year } \\
\text { published }\end{array}$ & $\begin{array}{l}\text { Age } \\
\text { (years)/ } \\
\text { Gender } \\
(M / F)\end{array}$ & $\begin{array}{l}\text { symptoms } \\
\text { of } \\
\text { FMF }\end{array}$ & $\begin{array}{l}\text { Neurological } \\
\text { findings } \\
\text { associated } \\
\text { with } \\
\text { meningitis }\end{array}$ & $\begin{array}{l}\text { Number } \\
\text { of } \\
\text { episodes } \\
\text { reported }\end{array}$ & $\begin{array}{l}\text { Age of } \\
\text { onset of } \\
\text { symptoms }\end{array}$ & $\begin{array}{l}\text { CSF } \\
\text { analysis } \\
\text { Cell (/ } \\
\mu L) \\
\text { Mono1 } \\
\text { (\%) } \\
\text { Protein } \\
\text { (mg/dL) }\end{array}$ & $\begin{array}{l}\text { MRI } \\
\text { findings }\end{array}$ & $\begin{array}{l}\text { MEFV } \\
\text { mutation }\end{array}$ & $\begin{array}{l}\text { Treatment } \\
\text { and } \\
\text { response }\end{array}$ \\
\hline & & & & & & & $\begin{array}{l}\text { Glucose } \\
\text { (mg/dL) }\end{array}$ & & & \\
\hline $\begin{array}{l}\text { Ref. \#8, } \\
\text { Hosoi, et al. }\end{array}$ & 2020 & $43 / M$ & $\begin{array}{l}\text { Fever, } \\
\text { arthritis } \\
\text { exertional } \\
\text { leg pain }\end{array}$ & $\begin{array}{l}\text { Recurrent } \\
\text { episodes of } \\
\text { fever and neck } \\
\text { pain }\end{array}$ & 2 & 43 & $\begin{array}{l}\text { Cell } 36 \\
\text { Mono } \\
97 \\
\text { Pro } 49 \\
\text { Glu } 57\end{array}$ & None & $\begin{array}{l}\text { E148Q/ } \\
\text { E148Q }\end{array}$ & $\begin{array}{l}\text { Colchicine } \\
0.5 \mathrm{mg} / \text { day }\end{array}$ \\
\hline $\begin{array}{l}\text { Ref. \#9, } \\
\text { Kinohshita } \\
\text { et al. }\end{array}$ & 2014 & $66 / F$ & Fever & $\begin{array}{l}10 \text { episodes of } \\
\text { meningitis in } \\
10 \text { months }\end{array}$ & 10 & 66 & $\begin{array}{l}\text { Cell } 35 \\
\text { PMN } \\
83 \% \\
\text { Pro } 77 \\
\text { Glu } 54\end{array}$ & $\begin{array}{l}\text { HIA of } \\
\text { cerebral } \\
\text { white } \\
\text { matter }\end{array}$ & $\begin{array}{l}\text { E148Q/ } \\
\text { E148Q }\end{array}$ & $\begin{array}{l}\text { No response } \\
\text { to } \\
\text { antibiotics } \\
\text { and antiviral } \\
\text { drugs. } \\
\text { Colchicine } \\
\text { prevented } \\
\text { the return of } \\
\text { symptoms. }\end{array}$ \\
\hline $\begin{array}{l}\text { Ref. \#10, } \\
\text { Yusef and } \\
\text { Khasawneh }\end{array}$ & 2017 & $13 / \mathrm{M}$ & Fever & $\begin{array}{l}\text { Meningeal } \\
\text { Signa }\end{array}$ & 3 & 13 & $\begin{array}{l}\text { Cell } 47 \\
\text { Mono } \\
97 \\
\text { Pro } 27 \\
\text { Glu } 80\end{array}$ & $\begin{array}{l}\text { No } \\
\text { lesions }\end{array}$ & $\begin{array}{l}\text { E148Q/ } \\
\text { E148Q }\end{array}$ & $\begin{array}{l}\text { Colchicine } \\
1 \text { mg/day, } \\
\text { no further } \\
\text { episodes } \\
\text { within } 6 \\
\text { months. }\end{array}$ \\
\hline $\begin{array}{l}\text { Ref. \#11, } \\
\text { Kimura et } \\
\text { al. }\end{array}$ & 2018 & $48 / F$ & $\begin{array}{l}\text { Fever, } \\
\text { arthritis } \\
\text { exertional } \\
\text { leg pain }\end{array}$ & $\begin{array}{l}\text { Convulsions - } \\
\text { decreased level } \\
\text { of } \\
\text { consciousness. } \\
\text { Severe } \\
\text { occipital } \\
\text { headache. }\end{array}$ & 1 & 45 & $\begin{array}{l}\text { Cell } 12 \\
\text { Pro } 154 \\
\text { Glu } 97\end{array}$ & $\begin{array}{l}\text { No } \\
\text { lesions }\end{array}$ & $\begin{array}{l}\text { L110P/ } \\
\text { E148Q }\end{array}$ & $\begin{array}{l}\text { Colchicine } \\
0.5 \mathrm{mg} / \mathrm{day} \\
\text { eradicated } \\
\text { her febrile } \\
\text { attacks and } \\
\text { headache. }\end{array}$ \\
\hline $\begin{array}{l}\text { Ref. \#12, } \\
\text { Sugie et al. }\end{array}$ & 2018 & $38 / \mathrm{M}$ & $\begin{array}{l}\text { Fever, } \\
\text { abdominal } \\
\text { pain }\end{array}$ & $\begin{array}{l}2 \text { weeks } \\
\text { headache and } \\
\text { nuchal rigidity }\end{array}$ & 1 & 5 & $\begin{array}{l}\text { Cell } 79 \\
\text { Mono } \\
47 \\
\text { Pro N/A } \\
\text { Glu N/A }\end{array}$ & $\begin{array}{l}\text { No } \\
\text { lesions }\end{array}$ & $\begin{array}{l}\text { E148Q/ } \\
\text { S503C }\end{array}$ & $\begin{array}{l}\text { Colchicine } \\
1 \mathrm{mg} / \mathrm{day} . \\
\text { Response } \\
\text { within } \\
3 \text { days. No } \\
\text { recurrence } \\
\text { within } \\
1 \text { year. }\end{array}$ \\
\hline $\begin{array}{l}\text { REf \#24 } \\
\text { Schwabe et } \\
\text { al. }\end{array}$ & 1988 & $32 / \mathrm{M}$ & $\begin{array}{l}\text { Fever, } \\
\text { pleuritis, } \\
\text { peritonitis, } \\
\text { arthritis }\end{array}$ & $\begin{array}{l}\text { Headache, } \\
\text { nuchal rigiditiy }\end{array}$ & & & $\begin{array}{l}\text { Missing } \\
\text { data }\end{array}$ & $\begin{array}{l}\text { No } \\
\text { lesions }\end{array}$ & None & \\
\hline $\begin{array}{l}\text { Ref. \# 23, } \\
\text { Vilaseca et } \\
\text { al. }\end{array}$ & 1982 & $33 / M$ & $\begin{array}{l}\text { Fever, } \\
\text { arthritis } \\
\text { Rash, } \\
\text { amyloidosis, } \\
\text { nephrotic } \\
\text { syndrome }\end{array}$ & $\begin{array}{l}\text { Headache, } \\
\text { fever }\end{array}$ & $\begin{array}{l}\text { Every } \\
\text { month } \\
\text { for } \\
11 \text { years } \\
\text { with } \\
\text { variable } \\
\text { intensity }\end{array}$ & 22 & $\begin{array}{l}\text { Cell } \\
1514, \\
80 \% \\
\text { PMN,, } \\
\text { Pro 94 } \\
\text { Glu } 58 \\
\text { Cell } 54 \\
\text { lymph } \\
100 \%, \\
\text { glu 63, } \\
\text { pro 34, }\end{array}$ & $\begin{array}{l}\text { No } \\
\text { imaging }\end{array}$ & None & $\begin{array}{l}\text { Several } \\
\text { antibiotics } \\
\text { courses. } \\
\text { Began } \\
\text { colchicine } \\
1 \mathrm{mg} / \text { day } \\
\text { and } \\
\text { symptoms } \\
\text { resolved for } \\
\text { at least } \\
3 \text { years of } \\
\text { follow up, } \\
\text { but } \\
\text { amyloidosis } \\
\text { developed. }\end{array}$ \\
\hline
\end{tabular}




\begin{tabular}{|c|c|c|c|c|c|c|c|c|c|c|}
\hline \multirow[t]{2}{*}{ Reference } & \multirow[t]{2}{*}{$\begin{array}{l}\text { Year } \\
\text { published }\end{array}$} & \multirow[t]{2}{*}{$\begin{array}{l}\text { Gender } \\
(\mathrm{M} / \mathrm{F})\end{array}$} & \multirow[t]{2}{*}{ FMF } & \multirow[t]{2}{*}{$\begin{array}{l}\text { Neurological } \\
\text { findings } \\
\text { associated } \\
\text { with } \\
\text { meningitis }\end{array}$} & \multirow[t]{2}{*}{$\begin{array}{l}\text { Number } \\
\text { of } \\
\text { episodes } \\
\text { reported }\end{array}$} & \multirow[t]{2}{*}{$\begin{array}{l}\text { Age of } \\
\text { onset of } \\
\text { symptoms }\end{array}$} & $\begin{array}{l}\text { CSF } \\
\text { analysis } \\
\text { Cell (/ } \\
\text { ML) } \\
\text { Mono1 } \\
\text { (\%) } \\
\text { Protein } \\
\text { (mg/dL) }\end{array}$ & \multirow[t]{2}{*}{$\begin{array}{l}\text { MRI } \\
\text { findings }\end{array}$} & \multirow[t]{2}{*}{$\begin{array}{l}\text { MEFV } \\
\text { mutation }\end{array}$} & \multirow[t]{2}{*}{$\begin{array}{l}\text { Treatment } \\
\text { and } \\
\text { response }\end{array}$} \\
\hline & & & & & & & $\begin{array}{l}\text { Glucose } \\
\text { (mg/dL) }\end{array}$ & & & \\
\hline \multirow{4}{*}{$\begin{array}{l}\text { Present } \\
\text { case }\end{array}$} & \multirow[t]{4}{*}{2020} & \multirow[t]{4}{*}{$14 / F$} & \multirow{4}{*}{$\begin{array}{l}\text { Abdominal } \\
\text { pain, fever, } \\
\text { erysipelas- } \\
\text { like rash }\end{array}$} & \multirow{4}{*}{$\begin{array}{l}\text { Headache, } \\
\text { fever, vomiting, } \\
\text { photophobia }\end{array}$} & \multirow{4}{*}{$\begin{array}{l}\text { Atleast } \\
10 \text { in } \\
7 \text { years. }\end{array}$} & \multirow[t]{4}{*}{7} & Cells 55 & \multirow{4}{*}{$\begin{array}{l}\text { No } \\
\text { lesions }\end{array}$} & M694V & \multirow{4}{*}{$\begin{array}{l}\text { No response } \\
\text { to colchicine } \\
2 \mathrm{mg} / \mathrm{day} \text {. } \\
\text { Full } \\
\text { response to } \\
\text { anakinra } \\
100 \mathrm{mg} / \text { day }\end{array}$} \\
\hline & & & & & & & 200 & & M694V & \\
\hline & & & & & & & $\begin{array}{l}\text { Pro } 40- \\
75\end{array}$ & & & \\
\hline & & & & & & & Glu 75 & & & \\
\hline
\end{tabular}

Current diagnostic criteria for RAM related to FMF are: (a) RAM episodes due to FMF should be accompanied by other clinical or biological features of FMF attacks; (b) Colchicine prevents or lessens episodes; and (c) other classical causes of RAM (drugs, HSV2 infection, systemic diseases and cystic brain lesions) should be excluded ${ }^{4}$. Our patient fulfilled both criteria for FMF and at least two of the criteria for RAM related to FMF. Only seven confirmed cases investigating association between FMF and RAM were found in the systemic review, although the differential diagnosis was incomplete in three cases. Most of the patients described on those case reports were heterozygotes to the E148Q mutation. It is controversial weather E148Q alternation is an insignificant variant or a disease-causing mutation. It seems that patients with only E148Q mutation are presenting with late-onset and milder disease course despite having similar clinical findings as compared with patients who had other mutations. ${ }^{22}$ Therefor it is questionable weather RAM in those cases is part of the FMF manifestations or can be explain by an alternative diagnosis.

On the contrary, in our case report, the patient was diagnosed with M694V mutation homozygosity, and there was no other phenotype implying for other diagnosis. The fast response observedto the treatment with IL-1 antagonist strengthen the presumed efficacy of anakinra in the FMF patients with CNS involvement.

Colchicine is the main therapeutic modality for reducing inflammatory attacks and preventing amyloidosis due to FMF. Nevertheless, $30-40$ percent of FMF patients continue to suffer from recurrent attacks despite therapy, and 5-10 percent are considered resistant to colchicine ${ }^{5}$. Until recently there was no other known effective treatment for FMF.

The revelation that FMF is caused by mutations in the MEFV gene, which encodes for the pyrin protein, increased understanding of the pathological events in the disease. The functional role of pyrin was discovered only recently ${ }^{19}$. Based on the role of pyrin in the regulation of interleukin (IL)-1 $\beta$ activation, the efficacy of IL-1 inhibitors has been assessed in more than 60 cases, and in one controlled study of patients with FMF who were resistant or intolerant of colchicine $5,7,20,21$ ). The three commercially, currently available anti IL-1 drugs are anakinra, Rilonacept and Canakinumab. Anakinra, an IL1 receptor antagonist, is given subcutaneously on a daily basis, and has demonstrated its efficacy in other autoinflammatory disorders. An anakinra treatment has been shown to improve CNS involvement in patients with neonatal onset multisystem inflammatory disorder (NOMID), halting the progression of hearing loss in most patients treated with NOMID. ${ }^{20}$

Our study is the first report of RAM due to FMF that is responsive to anakinra. The immediate response strongly suggests there was a relationship between FMF and RAM in this patient. Our experience also offers a novel therapeutic option for cochicine resistent RAM and maybe even other CNS manifestations of FMF.

\section{List Of Abbreviations}

Familial Mediterranean fever (FMF), central nervous system (CNS), Inerleukin 1 (IL-1), recurrent aseptic meningitis (RAM), polyarteritis nodosa (PAN), Serum Amyloid A (SAA), neonatal onset multisystem inflammatory disorder (NOMID), Magnetic resonance imaging (MRI), Magnetic resonance angiography (MRA), C-reactive protein (CRP), Cerebrospinal fluid (CSF), Polymerase chain reaction (PCR). Herpes simplex virus (HSV).

\section{Declarations}

\section{Ethics approval and consent to participate}

Not applicable.

\section{Consent for publication}

Not applicable. 
The authors declare that they have no competing interests.

\section{Availability of data and materials}

The datasets used and/or analyzed during the current study are available from the corresponding author on reasonable request.

\section{Funding}

No funding was secured for this study.

\section{Authors' contributions}

$\mathrm{RL}$ and YBA conceptualized and designed the study, drafted the initial manuscript, and reviewed and revised the manuscript.

YB collected the data and reviewed and revised the manuscript.

RB reviewed and revised the manuscript and treated the patient.

All authors approved the final manuscript as submitted and agree to be accountable for all aspects of the work.

\section{Acknowledgements}

Not applicable.

\section{References}

1. Sohar E, Gafni J, Pras M, Heller H. Familial Mediterranean fever. A survey of 470 cases and review of the literature. Am J Med. 1967;43(2):227-253. doi:10.1016/0002-9343(67)90167-2

2. Chae JJ, Aksentijevich I, Kastner DL. Advances in the understanding of familial Mediterranean fever and possibilities for targeted therapy. Br $\mathrm{J}$ Haematol. 2009;146(5):467-478. doi:10.1111/j.1365-2141.2009.07733.x

3. Feld O, Yahalom G, Livneh A. Neurologic and other systemic manifestations in FMF: published and own experience. Best Pract Res Clin Rheumatol. 2012;26(1):119-133. doi:10.1016/j.berh.2012.01.004

4. Capron J, Grateau G, Steichen O. Is recurrent aseptic meningitis a manifestation of familial Mediterranean fever? A systematic review. Clin Exp Rheumatol. 2013;31 suppl 77:127-32

5. Ben-Chetrit E, Ozdogan H. Non-response to colchicine in FMF-definition, causes and suggested solutions. Clin Exp Rheumatol 2008;26 Suppl 50:4951.

6. Özen S, Bilginer Y, Ayaz NA, Calguneri M. Anti-interleukin 1 treatment for patients with familial Mediterranean fever resistant to colchicine. J Rheumatol. 2011;38(3):516-518. doi:10.3899/jrheum.100718

7. van der Hilst JC, Moutschen M, Messiaen PE, Lauwerys BR, Vanderschueren S. Efficacy of anti-IL-1 treatment in familial Mediterranean fever: a systematic review of the literature. Biologics. 2016;10:75-80. doi:10.2147/BTT.S102954

8. Hosoi T, Ishii K, Tozaka N, Kishida D, Sekijima Y, Tamaoka A. Familial Mediterranean Fever Is Important in the Differential Diagnosis of Recurrent Aseptic Meningitis in Japan. Intern Med. 2020;59(1):125-128. doi:10.2169/internalmedicine.3432-19

9. Kinohshita T, Matsushima A, Satoh S, Hoshi K, Kishida D, Yahikozawa H. A case of colchicine-responsive Mollaret's meningitis with MEFV gene mutation. Clin Neurol. 2014;54(2):124-129. doi:10.5692/clinicalneurol.54.124

10. Yusef D, Khasawneh W. Familial Mediterranean Fever Presenting with Recurrent Aseptic Meningitis: A Case Report. Pediatr Neonatol. 2017;58(4):378379. doi:10.1016/j.pedneo.2016.03.012

11. Kimura K, Mizooka M, Migita K, et al. Five Cases of Familial Mediterranean Fever in Japan: The Relationship with MEFV Mutations. Intern Med. 2018;57(16):2425-2429. doi:10.2169/internalmedicine.0057-17

12. Sugie M, Ouchi T, Kishida D, Yasaki S. Atypical type of familial Mediterranean fever: An underdiagnosed cause of chronic aseptic meningitis. Neurol Clin Neurosci. 2018;6(6):191-193. doi:10.1111/ncn3.12232

13. Livneh A, Langevitz P, Zemer D, et al. Criteria for the diagnosis of familial Mediterranean fever. Arthritis Rheum. 1997;40(10):1879-1885. doi:10.1002/art.1780401023

14. Gökalp HZ, Başkaya MK, Aydin V. Pseudotumor cerebri with familial Mediterranean fever. Clin Neurol Neurosurg. 1992;94(3):261-263. doi:10.1016/0303-8467(92)90101-8

15. Lossos A, Eliashiv S, Ben-Chetrit E, Reches A. Optic neuritis associated with familial mediterranean fever. J Clin Neuroophthalmol. 1993;13(2):141143.

16. Henckes M, Roskams T, Vanneste S, Van Damme B, Vanrenterghem Y. Polyarteritis nodosa type vasculitis in a patient with familial Mediterranean fever treated with cyclosporin A. Transpl Int. 1994;7(4):292-296. doi:10.1007/BF00327159 
17. Yücesan C, Canyiǧit A, Türkçapar N. The coexistence of familial Mediterranean fever with multiple sclerosis [2]. Eur J Neurol. 2004;11(10):716-717. doi:10.1111/j.1468-1331.2004.00877.x

18. Uluduz D, Tavsanli ME, Uygunoğlu U, et al. Primary headaches in pediatric patients with chronic rheumatic disease. Brain Dev. 2014;36(10):884-891. doi:10.1016/j.braindev.2014.01.009

19. Gavrilin MA, Abdelaziz DHA, Mostafa M, et al. Activation of the Pyrin Inflammasome by Intracellular Burkholderia cenocepacia . J Immunol. 2012;188(7):3469-3477. doi:10.4049/jimmunol.1102272

20. Meinzer U, Quartier P, Alexandra J-F, Hentgen V, Retornaz F, Koné-Paut I. Interleukin-1 targeting drugs in familial Mediterranean fever: a case series and a review of the literature. Semin Arthritis Rheum. 2011;41(2):265-271. doi:10.1016/j.semarthrit.2010.11.003

21. Hashkes P, Butbul Aviel Y, Lubin S, Ben-Dayan E, Tseng L, Brik R. A76: Long-Term Efficacy of Canakinumab in Childhood Colchicine Resistant Familial Mediterranean Fever. Arthritis Rheumatol. 2014;66:S108-S108. doi:10.1002/art.38492

22. Aydin F, Cakar N, Valcinkaya F, et al. Clinical features and disease severity of Turkish FMF children carrying E148Q mutation. J Clin Lab Anal. 2019;33(4):e22852. Doi: 10.1002/jcla.22852

23. Vilaseca J, Tor J, Guardia J, Bacardi R. Periodic Meningitis and Familial Mediterranean Fever. Arch Intern Med. 1982;142(2):378-379. doi:10.1001/archinte.1982.00340150178031

24. Schwabe AD, Monroe JB. Meningitis in familial mediterranean fever. Am J Med. 1988;85(5):715-717. doi:10.1016/S0002-9343(88)80248-1

25. Soriano, A., Verecchia, E., Afeltra, A. et al.IL-1ß Biological Treatment of Familial Mediterranean Fever. Clinic Rev Allerg Immuno. 2013; 45:117-130. doi.org/10.1007/s12016-013-8358-y 